\title{
Effects of Pasture Feeding During the Periparturient Period on Postpartum Anovulation in Grazed Dairy Cows ${ }^{1}$
}

\author{
C. R. Burke ${ }^{2}$ and J. R. Roche ${ }^{3}$ \\ Dexcel Limited, Private Bag 3221, Hamilton, New Zealand
}

\section{ABSTRACT}

Extended postpartum anovulatory intervals (PPAI) are a major contributor to infertility in seasonal dairy systems constrained to 365 -d calving intervals. This study was conducted to evaluate the effects of pasturebased dietary energy intakes during the transitional calving period on PPAI. Sixty-eight multiparous Holstein-Friesian cows were assigned to high [11.9 kg of dry matter $(\mathrm{DM}) / \mathrm{d}]$ or low $(4.8 \mathrm{~kg}$ of $\mathrm{DM} / \mathrm{d})$ pasture intakes for $29 \pm 7.7 \mathrm{~d}$ prepartum. After calving, cows within each prepartum diet were assigned to either a high (13.5 kg of DM/d) or low ( $8.6 \mathrm{~kg}$ of DM/d) pasture intake for $35 \mathrm{~d}$ in a $2 \times 2$ factorial arrangement. Progesterone concentrations were measured in milk samples collected twice weekly to determine PPAI, which was defined as the day on which progesterone level was elevated to $\geq 3 \mathrm{ng} / \mathrm{mL}$ with subsequent concentrations being consistent with an ovulatory cycle. Blood samples were collected before initiation of treatments, and at $\mathrm{d}-21,-14,-7,0$ (day of calving), $1,2,3,4,7,14$, 21,28 , and 35 in all cows. The PPAI was associated with body condition score, concentrations of plasma insulin and insulin-like growth factor-I, and growth hormone. Postpartum intake did not affect these metabolic hormones or PPAI, but yield of FCM during the first $35 \mathrm{~d}$ was reduced by $23 \%$ among cows on a restricted intake. No relationships were found between PPAI and milk production characteristics. These data demonstrate that when pasture is the sole dietary source during the calving transition period, PPAI may be influenced by prepartum intake levels, whereas postpartum intake influences milk yield, but not PPAI. The underlying mechanism(s) that associates the prepartum period to PPAI may involve the sensitivity of

\footnotetext{
Received November 26, 2006.

Accepted May 30, 2007.

${ }^{1}$ This study was funded by the New Zealand Foundation for Research, Science and Technology through Contract DRCX0204 and by New Zealand dairy farmers through Dairy InSight.

${ }^{2}$ Corresponding author: chris.burke@dexcel.co.nz

${ }^{3}$ Present address: University of Tasmania, School of Agricultural Science, PO Box 3523, Burnie, Tasmania 7320, Australia.
}

the growth hormone-insulin-like growth factor axis to dietary intake levels. Nonetheless, PPAI in grazing multiparous dairy cows appears largely unresponsive to intake levels during the calving transition period. Key words: postpartum anovulation, metabolic hormones, reproduction, nutrition

\section{INTRODUCTION}

Prolonged postpartum anovulatory intervals (PPAI) are a major risk factor for reduced reproductive performance in dairy herds, particularly in seasonal systems with a confined breeding period based on calendar dates and optimized for a 365-d calving interval. Cows with prolonged PPAI are less likely to be mated within the early part of the breeding period (Macmillan, 2002), have reduced conception rates (Darwash et al., 1997; Westwood et al., 2002), and are more likely culled (Opsomer et al., 2000). Several factors can prolong PPAI and result in high anestrous rates in grazing dairy cows (Macmillan, 2002; Rhodes et al., 2003). These can be animal characteristics such as age, breed, and genetic strain within breed (Burke et al., 1995; McDougall et al., 1995b; McNaughton et al., 2003), features of the farm system, such as stocking density and feeding level (Grainger and Wilhelms, 1979; McDougall et al., 1995b), and interactive factors such as disease (McDougall et al., 2007) and body condition (Grainger et al., 1982; Roche et al., 2007).

The physiological effects of nutritional stress on ovarian follicular function and postpartum anestrus were reviewed (Jolly et al., 1995; Diskin et al., 2003). Although large dominant follicles reestablish on the ovaries within several days after calving (McDougall et al., 1995a), endocrine conditions required for final maturation and first ovulation postpartum are influenced by body fat reserves, energy balance, and metabolic state (Grainger et al., 1982; Butler and Smith, 1989). An understanding of how these nutritional considerations influence reproductive events is building (Robinson et al., 2006), but the mechanisms remain complex and inadequately understood.

The issue of calving transition ( -3 wk to +3 wk of calving) management on fertility was reviewed (For- 
migoni and Trevisi, 2003; Rhoads et al., 2005), indicating that energy deficit coupled with a period of suppressed immune function is largely responsible for compromised reproductive performance. With the exception of some early studies involving cows with a 1970s genetic base (Grainger and Wilhelms, 1979; Grainger et al., 1982), there are no controlled studies that specifically investigate the effects of pre- and postpartum DMI levels, and their interaction, on PPAI of lactating dairy cows in a seasonal system. This study was designed and conducted to evaluate the effect of pre- and postpartum levels of pasture feeding on PPAI of seasonally managed lactating dairy cows. To better understand the mechanisms underlying these outcomes, an objective was to investigate the association between PPAI and metabolic indicators.

\section{MATERIALS AND METHODS}

This study was conducted at Dexcel, Hamilton, New Zealand $\left(37^{\circ} 46^{\prime} \mathrm{S}, 175^{\circ} 18^{\prime}\right.$ E) between July and September 2004. All procedures had prior approval of the Ruakura Animal Ethics Committee, New Zealand.

\section{Experimental Design and Cow Management}

At $29 \pm 7.7 \mathrm{~d}$ (mean $\pm \mathrm{SD}$ ) prepartum, 68 multiparous Holstein-Friesian cows predicted to calve within the first $21 \mathrm{~d}$ of a seasonal calving period were randomly allocated either a high (PreH; $11.9 \mathrm{~kg} / \mathrm{d} \mathrm{DM})$ or low pasture intake (PreL; $4.8 \mathrm{~kg} / \mathrm{d} \mathrm{DM})$, while ensuring treatment groups were balanced for milk yield in the previous lactation, BW, BCS, age, and predicted calving date. At calving, half of the cows within each prepartum feeding treatment were randomly allocated to either a high (HH and LH; $13.5 \mathrm{~kg} / \mathrm{d} \mathrm{DM}$ ) or low pasture intake (HL and $\mathbf{L L} ; 8.6 \mathrm{~kg} / \mathrm{d} \mathbf{D M}$ ) for $35 \mathrm{~d}$, as a $2 \times 2$ factorial arrangement with 17 cows per treatment cell. At $35 \mathrm{~d}$ postpartum, all cows were grouped as a single herd on fresh pasture supplemented with pasture-silage $(6.1 \pm 1.7 \mathrm{~kg} / \mathrm{d} \mathrm{DM})$ for $3 \mathrm{wk}$ and thereafter managed solely on fresh pasture.

Detailed descriptions of grazing management, measurements of pasture intakes, and milk production characteristics have been published (Roche, 2007). Briefly, animals were rotationally grazing through 56 paddocks, with a fresh grazing area offered twice daily. Pasture consisted mostly ( $\geq 85 \%$ ) of perennial ryegrass (Lolium perenne L.). Treatment groups grazed within the same paddock at all times, but within a defined grazing area to achieve differential intakes. Pre- and postgrazing herbage masses and grazing area allocations were used to control average pasture intakes for cows within treatments. Herbage masses were assessed using a Rising Plate Meter (Farmworks, Palmerston North, New Zealand), which measures compressed pasture height. These measurements (100 per treatment before and after grazing) were calibrated to DM yields from cut and dried pasture samples $(20 \times$ $0.125 \mathrm{~m}^{2}$ quadrats per treatment) thrice weekly. On each of these occasions, a "hand-plucked" sample to grazing height was collected. These samples were bulked at 2 weekly intervals and analyzed for DM content and nutrient composition. Average $( \pm$ SD) $\mathrm{ME}$ estimates of pasture for PreH and PreL were $11.6 \pm$ 0.31 and $11.7 \pm 0.09 \mathrm{MJ} / \mathrm{kg}$ of DM, respectively. Respective values after calving for high and low pasture intake treatments were $12.1 \pm 0.21$ and $12.3 \pm 0.07 \mathrm{MJ} / \mathrm{kg}$ of DM. A detailed description of botanical and nutrient composition of the pasture fed during the current study is in Roche (2007).

Individual BW and BCS (1 to 10 scale; Roche et al., 2004) were measured weekly throughout the study. Individual milk yields were measured at each milking and compositional characteristics were determined twice weekly until $35 \mathrm{~d}$ postpartum.

\section{Blood Sampling Regimen}

Blood samples were collected from all cows by coccygeal venipuncture into evacuated tubes containing sodium heparin before treatment allocation on $\mathrm{d}-21$, $-14,-7,0$ (day of calving), 1, 2, 3, 4, 7, 14, 21, 28, 35, and weekly thereafter for individuals until confirmed as cycling. Sampling time was approximately $0730 \mathrm{~h}$. Plasma was harvested after centrifugation $(1,120 \times g$ for $12 \mathrm{~min}$ ) and stored at $-17^{\circ} \mathrm{C}$.

\section{PPAI Determination}

Progesterone was measured in a composite of milk samples collected at the Monday p.m.-Tuesday a.m. and Thursday p.m.-Friday a.m. milking each week from calving until cows were confirmed as cycling. Progesterone content was determined using an ELISA kit (Ridgeway Sciences, Gloucestershire, UK) validated for use in cattle (Sauer et al., 1986). The PPAI was defined as the interval from calving to the first day that progesterone concentration increased to $\geq 3 \mathrm{ng} /$ $\mathrm{mL}$, with subsequent concentrations being consistent with the onset of ovulatory cycles. The PPAI was not measured in 6 cows (last sampled 51 to $77 \mathrm{~d}$ postpartum; HH, 2; LH, 3; HL, 0; LL, 1), but PPAI estimates were generated using the CENSOR procedure (GenStat 5.4.1, GenStat for Windows, 9th ed., VSN International Ltd., Hemel Hempstead, UK). These cows had not ovulated before onset of the seasonal breeding pe- 
Table 1. Least squares means of daily milk yield and composition during the first $35 \mathrm{~d}$ lactation and postpartum anovulatory intervals (PPAI) in cows fed differing amounts of pasture pre- and postpartum

\begin{tabular}{|c|c|c|c|c|c|c|c|c|}
\hline \multirow[b]{2}{*}{ Variable } & \multicolumn{4}{|c|}{ Treatment group $^{1}$} & \multirow[b]{2}{*}{$\mathrm{SED}^{2}$} & \multicolumn{3}{|c|}{$P$-value ${ }^{1}$} \\
\hline & $\mathrm{HH}$ & HL & $\mathrm{LH}$ & LL & & Pre & Post & Pre $\times$ Post \\
\hline Milk, kg/d & 25.56 & 18.54 & 24.43 & 18.92 & 0.94 & 0.6 & $<0.01$ & 0.2 \\
\hline $\mathrm{FCM},{ }^{3} \mathrm{~kg} / \mathrm{d}$ & 28.46 & 21.25 & 26.00 & 20.82 & 1.12 & 0.07 & $<0.01$ & 0.2 \\
\hline $\mathrm{NE}_{\mathrm{L}},{ }^{4} \mathrm{MJ} / \mathrm{d}$ & 89.0 & 65.4 & 81.5 & 64.4 & 0.1 & 0.07 & $<0.01$ & 0.2 \\
\hline Fat, kg/d & 1.22 & 0.92 & 1.08 & 0.88 & 0.05 & 0.02 & $<0.01$ & 0.2 \\
\hline Protein, kg/d & 0.94 & 0.65 & 0.87 & 0.65 & 0.03 & 0.2 & $<0.01$ & 0.09 \\
\hline Lactose, $\mathrm{kg} / \mathrm{d}$ & 1.23 & 0.90 & 1.18 & 0.91 & 0.05 & 0.5 & $<0.01$ & 0.3 \\
\hline Fat, \% & 4.76 & 5.01 & 4.41 & 4.66 & 0.13 & $<0.01$ & $<0.01$ & 0.9 \\
\hline Protein, \% & 3.68 & 3.52 & 3.56 & 3.43 & 0.06 & 0.02 & $<0.01$ & 0.7 \\
\hline PPAI, d & 34.7 & 29.2 & 40.4 & 37.0 & 6.3 & 0.07 & 0.4 & 0.8 \\
\hline
\end{tabular}

\footnotetext{
${ }^{1}$ Cows received high or low (11.9 vs. $4.8 \mathrm{~kg} / \mathrm{d} \mathrm{DM}$ ) pasture intakes prepartum (Pre) followed with high ( $\mathrm{HH}$ and $\mathrm{LH} ; 13.5 \mathrm{~kg} / \mathrm{d} \mathrm{DM}$ ) or low (HL and LL; $8.6 \mathrm{~kg} / \mathrm{d} \mathrm{DM}$ ) pasture intakes during the first 35 d postpartum (Post). Milk yield and composition data were published in detail elsewhere (Roche, 2007).

${ }^{2} \mathrm{SED}=$ standard error of the difference.

${ }^{3} \mathrm{FCM}=0.4 \times$ milk $(\mathrm{kg} / \mathrm{d})+15 \times \mathrm{kg}$ fat $(\mathrm{kg} / \mathrm{d})$.

${ }^{4} \mathrm{NE}_{\mathrm{L}}(\mathrm{MJ} /$ cow per $\mathrm{d})=(0.0929 \times$ Fat $\%)+(0.0547 \times \mathrm{CP} \%)+(0.0395 \times$ Lactose $\%) \times 4.186 \mathrm{MJ} / \mathrm{Mcal} \times$ $\mathrm{kg} / \mathrm{d}$ milk/cow.
}

riod, at which time they received a progesterone-based treatment for anestrus.

\section{Plasma Metabolite Measurements}

Plasma from each cow was analyzed for concentrations of NEFA (mmol/L; colorimetric method using a commercial kit (Wako, Osaka, Japan), BHBA (mmol/ L; BHBA dehydrogenase assay based on formation of acetoacetate and NADH after addition of NAD), glucose $(\mathrm{mmol} / \mathrm{L}$; hexokinase method based on formation of NADPH), albumin ( $\mathrm{g} / \mathrm{L}$; citrate buffer reagent), urea $\left(\mathrm{mmol} / \mathrm{L}\right.$; urease hydrolysis method), $\mathrm{Ca}^{++}(\mathrm{mmol} / \mathrm{L}$; ocresolphthalein complexone method) and $\mathrm{Mg}^{++}(\mathrm{mmol} /$ $\mathrm{L}$; xylidyl blue reaction). All assays were performed at $30^{\circ} \mathrm{C}$ using an Hitachi 717 analyzer (Roche, Basel, Switzerland) by Alpha Scientific Limited, Hamilton, New Zealand. The inter- and intraassay coefficients of variation $(\mathbf{C V})$ were $5 \%$ or less for all assays.

\section{Plasma Hormone Measurements}

All plasma samples were analyzed in duplicate for growth hormone (GH), IGF-I, and insulin using double-antibody RIA (Chagas et al., 2006). Intra- and interassay $\mathrm{CV}$ for $\mathrm{GH}$ were 8.4 and $<10.7 \%$, respectively; sensitivity of the $\mathrm{GH}$ assay was $0.19 \mathrm{ng} / \mathrm{mL}$. Intraand interassay CV for IGF-I were 8.8 and $<10.5 \%$, respectively; sensitivity of the IGF-I assay was $1 \mathrm{ng} /$ $\mathrm{mL}$. Intra- and interassay CV for insulin were 10.3 and $12.4 \%$, respectively; sensitivity of the insulin assays was $2 \mu \mathrm{IU} / \mathrm{mL}$.

\section{Statistical Analyses}

Data were analyzed using REML in GenStat 5.4.1 (VSN International Ltd.) with fixed effects of treatment in a $2 \times 2$ factorial arrangement and cow as the random effect. Repeated measures through time were modeled separately for pre- and postpartum periods using spline models within the linear mixed model framework (Verbyla et al., 1999). The $\log _{10}$ PPAI was analyzed using the CENSOR procedure in GenStat to test treatment effects, but the untransformed least squares means (LSM) are presented in results.

Associations between measured variables pooled within treatment and PPAI at individual time points or the mean value for each cow over the first $35 \mathrm{~d}$ postpartum were determined using CENSOR procedure. The $\log _{10}$ PPAI was used in testing significance of these associations. The GH, IGF-I, insulin, NEFA, and BHBA data were $\log _{10}$ transformed before analyses. Untransformed means are presented in results.

Variables that had a consistent association with variance in PPAI were defined as those with 3 or more sampling days being significant $(P<0.05)$. Variables with a consistent and relevant association were defined as those with at least 1 of the 3 significant sampling times accounting for $10 \%\left(\mathrm{R}^{2}>0.1\right)$ or more of the variance in PPAI. Variables described as having an inconsistent association with PPAI were those with 1 or 2 sampling times having significance $(P<0.05)$, whereas variables with no significant sampling times $(P>0.05)$ were defined as unrelated.

Data of 2 cows were excluded from general analyses because the animals were removed from the trial during the first $35 \mathrm{~d}$ postpartum. 


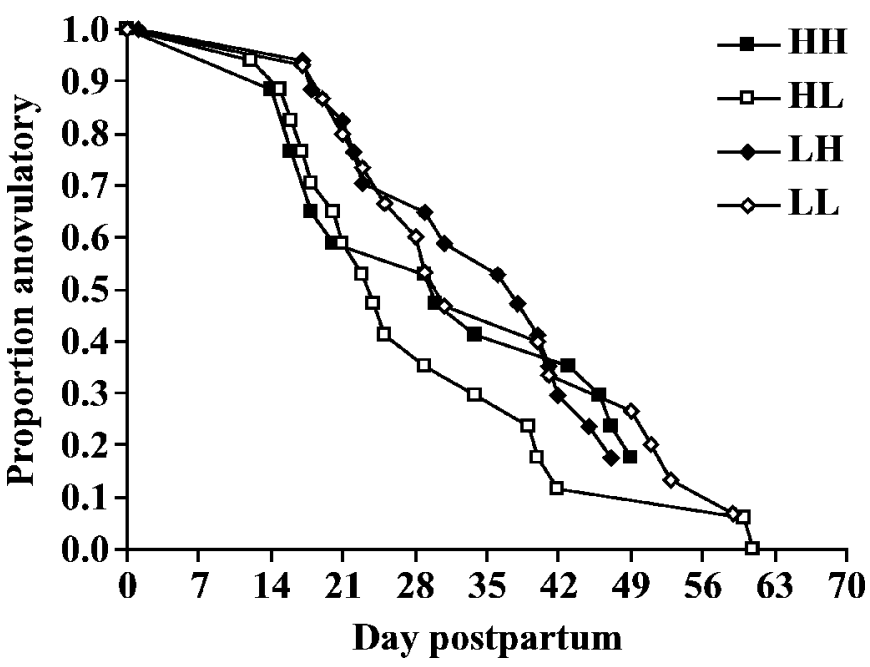

Figure 1. Proportion of cows anovulatory with time postpartum for those on a high (HH or HL; $11.9 \mathrm{~kg} / \mathrm{d} \mathrm{DM}$ ) or low prepartum intake (LH and LL; $4.8 \mathrm{k} / \mathrm{d} \mathrm{DM}$ ) followed with high (HH and LH; $13.5 \mathrm{~kg} / \mathrm{d} \mathrm{DM}$ ) or low (HL and LL; $8.6 \mathrm{~kg} / \mathrm{d} \mathrm{DM}$ ) pasture intakes postpartum. Survival curves exclude censored data estimates of 6 cows in which first ovulation was not detected within the experimental period.

\section{RESULTS}

\section{Dietary Treatment Effects on PPAI}

The PPAI tended $(P=0.07)$ to be shorter in cows on a PreH intake compared with those on a PreL pasture intake (32.0 vs. $38.7 \mathrm{~d}$; SED $=4.4)$. In addition, a greater $(P=0.01)$ proportion of cows on $\mathrm{PreH}$ had ovulated by $21 \mathrm{~d}$ postpartum than PreL cows ( $38 \pm 8 \%$ and $13 \pm 6 \%$, respectively), whereas anovulatory rates at $49 \mathrm{~d}$ postpartum $(18 \%)$ were similar $(P=0.5)$ among the prepartum intake groups (Figure 1). Postpartum intake did not affect PPAI $(P=0.4)$, nor was there a detectable interaction $(P=0.8)$ between pre- and postpartum treatments (Table 1).

\section{Milk Characteristics, BCS, and BW, and Associations with PPAI}

An interpretive summary of the consistency and relevance of associations between PPAI and treatmentdependent variables is in Table 2.

Cows on high pasture intakes postpartum had greater average daily milk yields, milk components, $\mathrm{NE}_{\mathrm{L}}$, and protein percentage in milk compared with those on a low intake postpartum (Table 1). Conversely, fat percentage in milk was reduced by a high postpartum intake (Table 1). Low pasture intakes prepartum reduced BCS $(P<0.01)$ from d -14 to 35 (Figure 2a). Postpartum diet had no effect $(P>0.10)$ on BCS, nor was there a prepartum by postpartum diet interac-
Table 2. Summary of analyses relating measured variables pooled within treatment to variance in postpartum anestrous intervals (PPAI)

\begin{tabular}{lcc}
\hline Variable & Consistency $^{1}$ & Relevance $^{2}$ \\
\hline BCS & $* * *$ & $* * *$ \\
BW & $*$ & - \\
Change ${ }^{3}$ in BCS & NS & - \\
Change $^{3}$ in BW & NS & - \\
Milk yield & NS & - \\
Fat and protein yield & NS & - \\
Protein yield & NS & - \\
Protein \% & NS & - \\
NE & NS & - \\
Growth hormone & $* * *$ & $* * *$ \\
IGF-I & $* * *$ & $* * *$ \\
Insulin & $*$ & - \\
Glucose & $*$ & - \\
Urea & NS & - \\
NEFA & NS & - \\
BHBA & $*$ & - \\
Albumin & $* * *$ & $* * *$ \\
Ca & NS & - \\
Mg & $*$ & - \\
\hline
\end{tabular}

${ }^{1}$ Consistency of any associations were defined respectively as consistent (***), inconsistent $(*)$, or unrelated (NS) when at least 3,1 to 2 , or no sampling time points were significantly $(P<0.05)$ associated with PPAI.

${ }^{2}$ Significant associations were described as relevant (***) where $\mathrm{R}^{2}$ $\geq 0.1$ for at least 1 significant sampling time point or irrelevant (-) where $R^{2}<0.1$ for all sampling time points of significance.

${ }^{3}$ Changes between $d-21$ to $-7, d-7$ to $21, d-7$ to 42 , and $d 7$ to 42 relative to calving $(\mathrm{d} 0)$.

tion. Low pasture intakes pre- or postpartum reduced BW $(P<0.001)$, with a prepartum by postpartum diet interaction $(P=0.04)$ detected on d 14 (Figure $2 b$ ).

\section{Metabolic Hormones}

Concentrations of GH (Figure 3a) were greater $(P<$ 0.01 ) in cows on PreL from $d-7$ to 7 and from $d 28$ to 35, compared with those on PreH intake. Postpartum diet had no effect $(P>0.10)$ on $\mathrm{GH}$. Concentrations of IGF-I (Figure 3b) were reduced $(P<0.001)$ from $d$ -21 to -7 in cows on PreL. There were no $(P>0.10)$ postpartum diet effects on IGF-I. Insulin concentrations (Figure 3c) were reduced $(P<0.001)$ from $d-21$ to -7 in cows on PreL. Postpartum diet had no effect on insulin $(P>0.10)$, nor were any interactions detected $(P>0.10)$.

\section{Metabolites}

Plasma glucose (Figure 4a) was greater prepartum (d -21 to $-7 ; P<0.001$ ) and immediately postpartum (d 2; $P=0.02$ ) in cows on PreH. Similarly, a high pasture intake postpartum increased plasma glucose on $\mathrm{d} 7,14$, and $28(P<0.05)$. There was no prepartum by postpartum diet interaction on plasma glucose. 


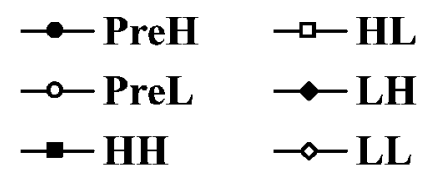

a)

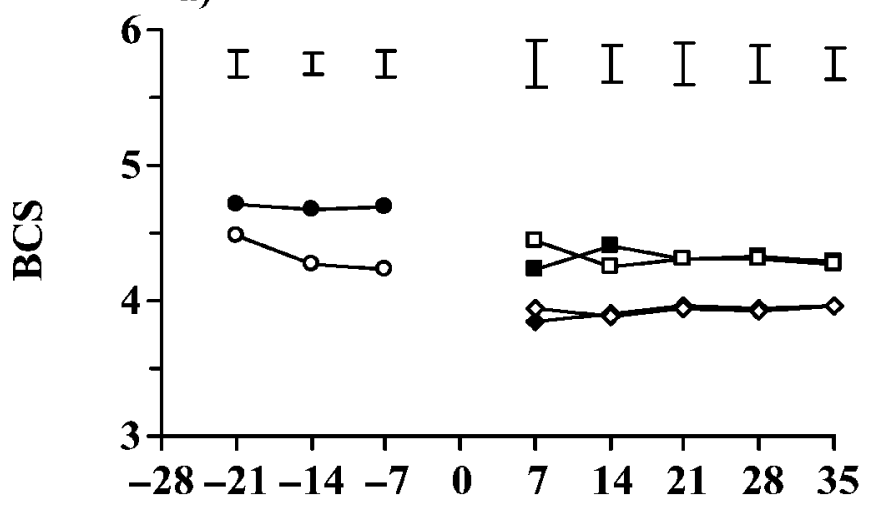

b)

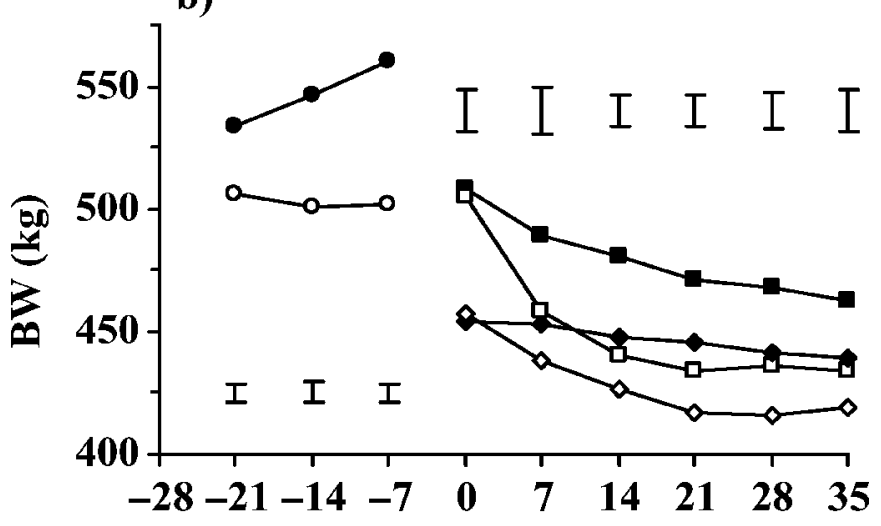

Day postpartum

Figure 2. Least squares means ( \pm 2 SED) of a) BCS ( 1 to 10 scale) and b) BW in cows with high (PreH; $11.9 \mathrm{~kg} / \mathrm{d}$ DM) or low (PreL; 4.8 $\mathrm{kg} / \mathrm{d} \mathrm{DM}$ ) pasture intakes prepartum followed with high ( $\mathrm{HH}$ and $\mathrm{LH}$; $13.5 \mathrm{~kg} / \mathrm{d} \mathrm{DM}$ ) or low (HL and LL; $8.6 \mathrm{~kg} / \mathrm{d} \mathrm{DM}$ ) pasture intakes postpartum.

Plasma concentrations of NEFA (Figure $4 \mathrm{~b}$ ) were elevated $(P<0.05)$ when pasture intakes were low during both the pre- and postpartum periods until d 28, with no detectable interaction $(P>0.10)$ between pre- and postpartum diet treatments. Plasma NEFA was not associated $(P>0.10)$ with variance in PPAI. Plasma BHBA (Figure 4c) was elevated $(P<0.001)$ from $d-21$ to -7 in cows on PreL. An interaction was detected during the postpartum period (d 3 to d 28; $P<0.05$ ), with cows on PreH and HL having elevated BHBA during this period, compared with similar concentrations among other groups. Plasma urea (Figure 4d) was greater $(P=0.04)$ on d 4 among cows on PreL. There were no postpartum diet differences on plasma

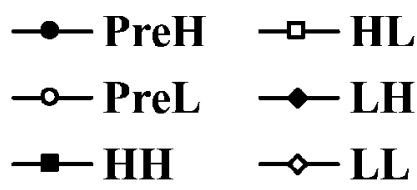

a)

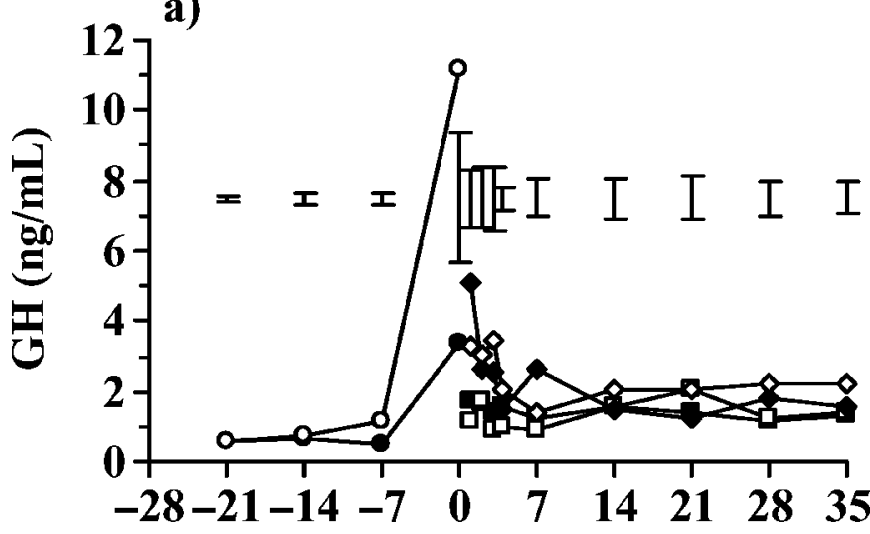

b)

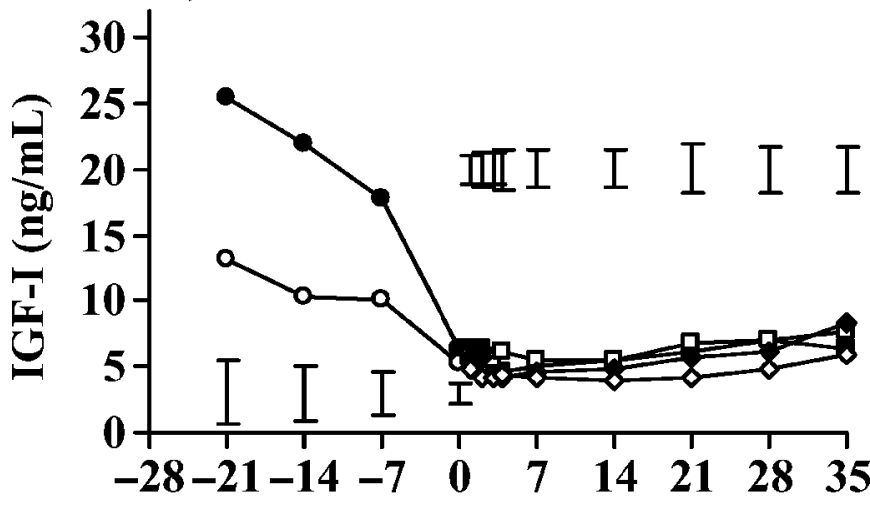

c)

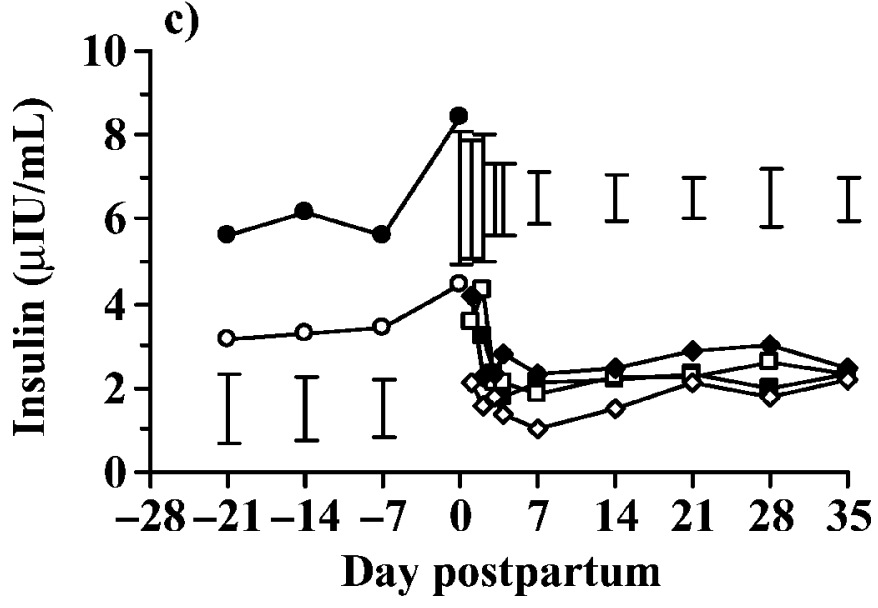

Figure 3. Least squares means ( \pm 2 SED) of plasma concentrations of a) growth hormone (GH), b) IGF-I, and c) insulin in cows with high (PreH; $11.9 \mathrm{~kg} / \mathrm{d} \mathrm{DM})$ or low (PreL; $4.8 \mathrm{~kg} / \mathrm{d} \mathrm{DM})$ pasture intakes prepartum followed with high (HH and LH; $13.5 \mathrm{~kg} / \mathrm{d} \mathrm{DM}$ ) or low (HL and LL; $8.6 \mathrm{~kg} / \mathrm{d} \mathrm{DM}$ ) pasture intakes postpartum. 
a)

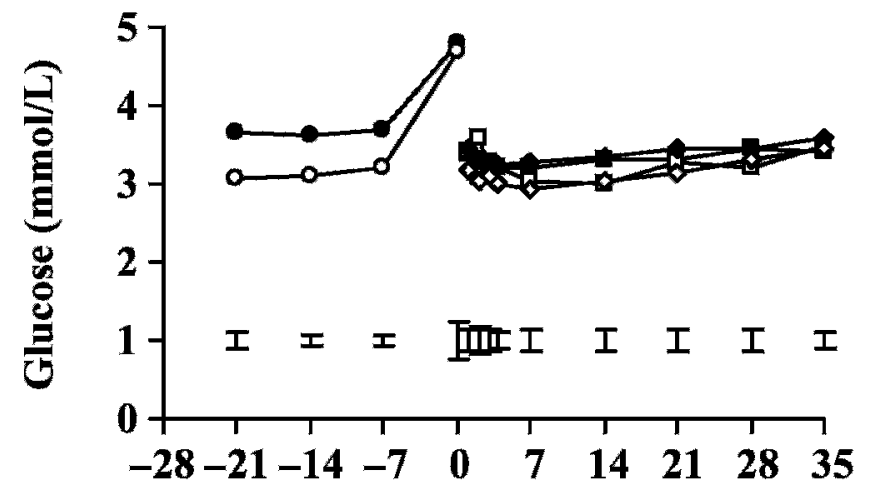

b)

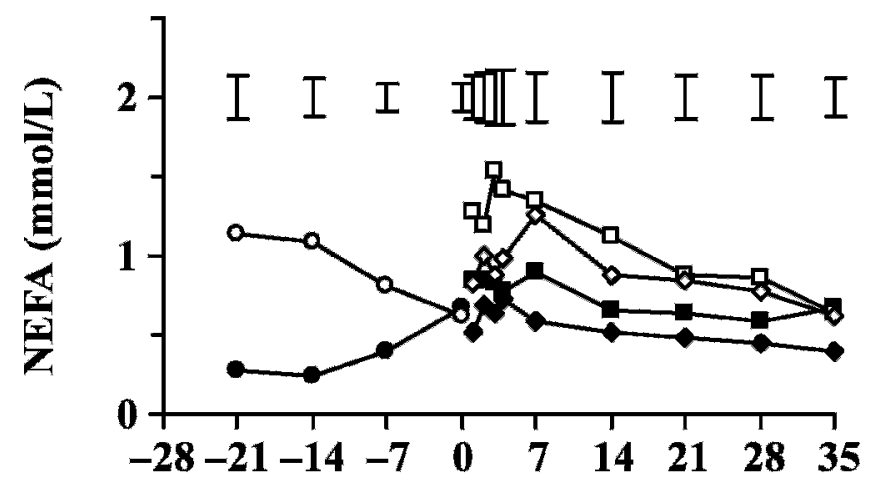

c)

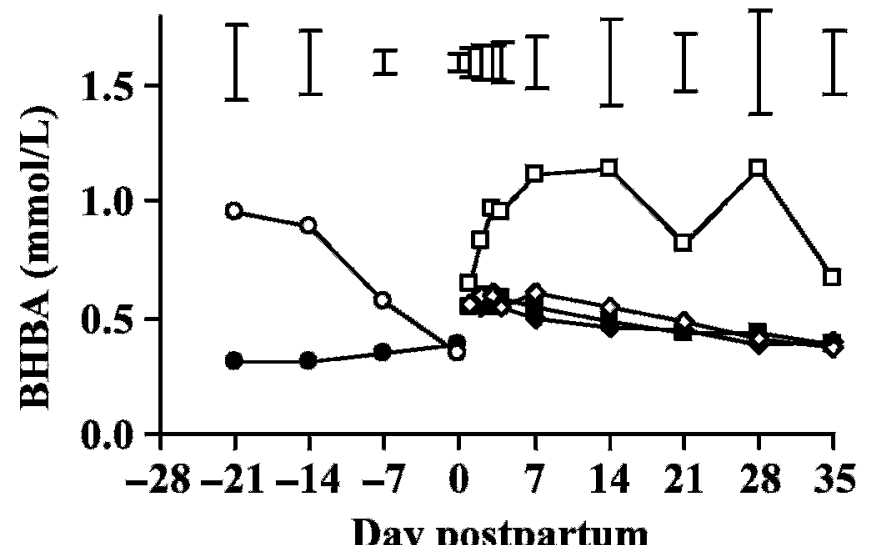

d)

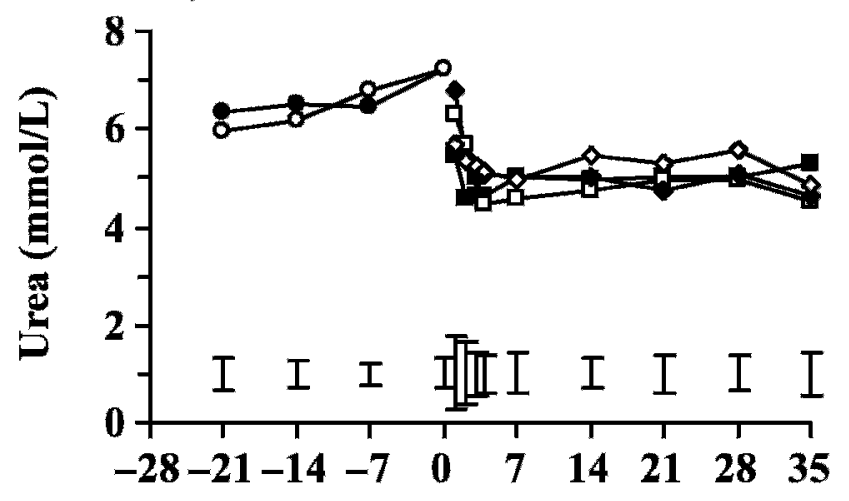

e)

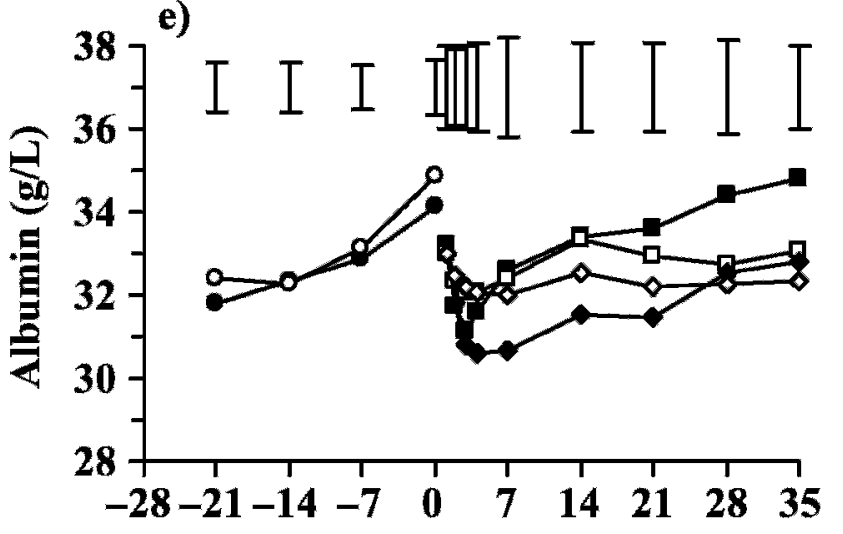

Day postpartum

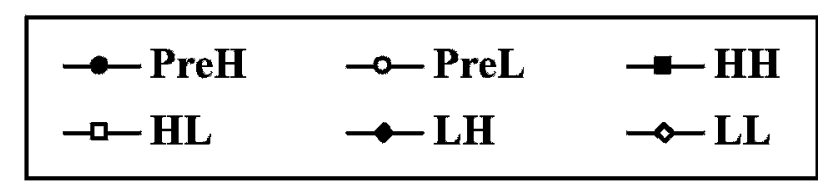

Figure 4. Least squares means ( \pm 2 SED) of plasma concentrations of a) glucose, b) NEFA, c) BHBA, d) urea, and e) albumin in cows with high (PreH; $11.9 \mathrm{~kg} / \mathrm{d} \mathrm{DM}$ ) or low (PreL; $4.8 \mathrm{~kg} / \mathrm{d} \mathrm{DM}$ ) pasture intakes prepartum followed with high (HH and LH; $13.5 \mathrm{~kg} / \mathrm{d}$ DM) or low (HL and LL; $8.6 \mathrm{~kg} / \mathrm{d} \mathrm{DM}$ ) pasture intakes postpartum.

urea concentrations, nor was an interaction detected. Plasma urea concentrations were not associated $(P>$ $0.10)$ with variance in PPAI. Concentrations of plasma albumin (Figure 4e) were not altered $(P>0.10)$ by intake.

\section{$\mathrm{Ca}^{++}$and $\mathrm{Mg}^{++}$}

Plasma $\mathrm{Ca}^{++}$concentrations (Figure 5a) were greater $(P<0.05)$ among cows on PreH on $\mathrm{d}-21$ and -14 , but then lower $(P<0.05)$ on d 0 to 3 , compared 


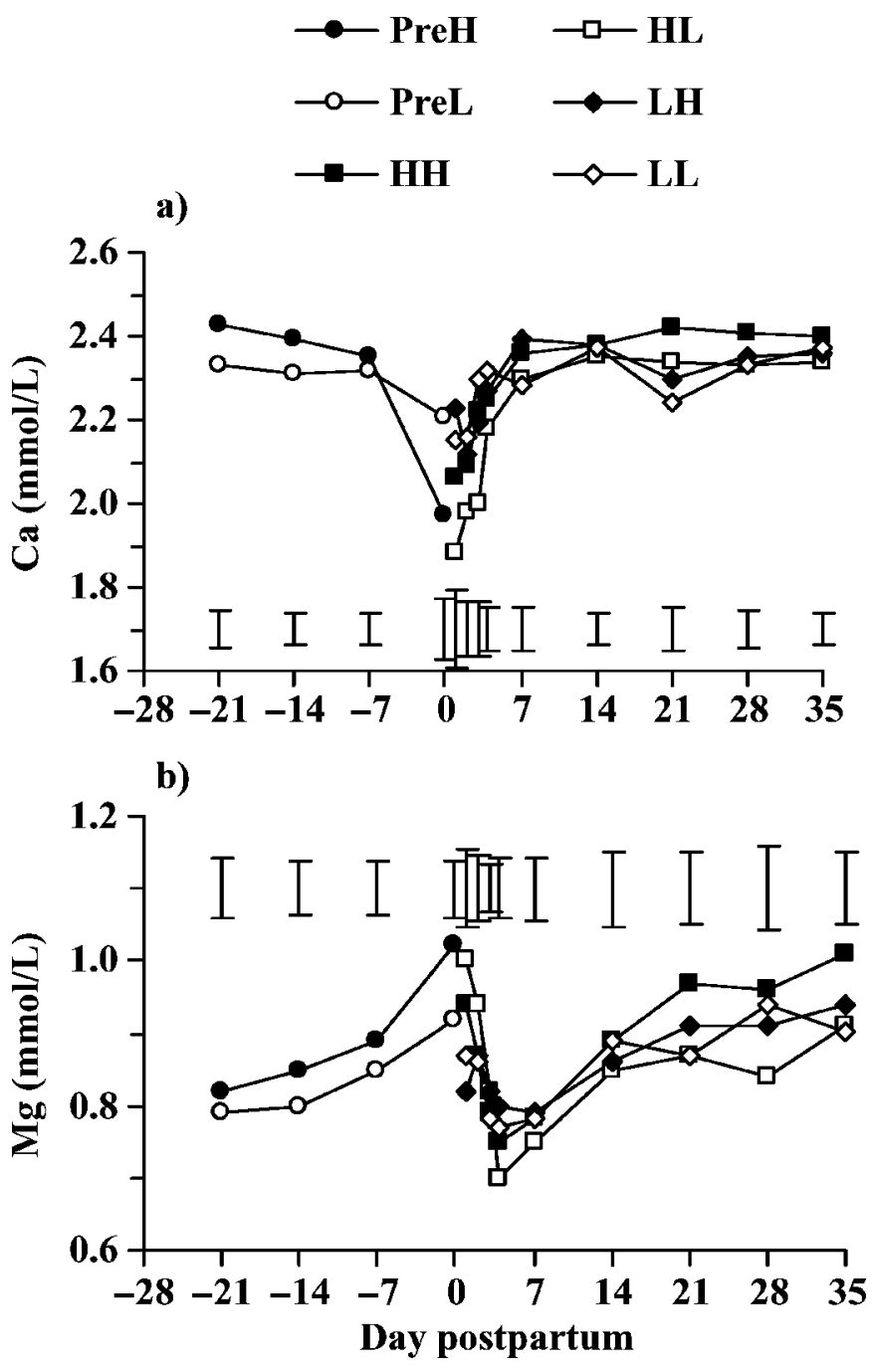

Figure 5. Least squares means ( \pm 2 SED) of plasma concentrations of a) calcium and b) magnesium in cows with high (PreH; $11.9 \mathrm{~kg} / \mathrm{d}$ DM) or low (PreL; $4.8 \mathrm{~kg} / \mathrm{d} \mathrm{DM}$ ) pasture intakes prepartum followed with high (HH and LH; $13.5 \mathrm{~kg} / \mathrm{d} \mathrm{DM}$ ) or low (HL and LL; $8.6 \mathrm{~kg} / \mathrm{d}$ DM) pasture intakes postpartum.

with those on PreL. Plasma $\mathrm{Ca}^{++}$was not associated $(P>0.10)$ with PPAI. Low pasture intakes prepartum reduced $(P<0.05)$ plasma $\mathrm{Mg}^{++}$(Figure $\left.5 \mathrm{~b}\right)$ on $\mathrm{d} 0$ and 1.

\section{DISCUSSION}

The PPAI of multiparous grazing dairy cows is remarkably unresponsive to pasture intake levels during the calving transition period. Low intakes prepartum perturbed the insulin-GH-IGF-I axis and promoted body condition loss. Contrasting levels of pasture intake postpartum affected milk yield and circulating concentrations of metabolites, but did not influence metabolic hormones, BCS, or PPAI. Various associa- tions were found among metabolic indicators and PPAI, but none that could explain more than $15 \%$ of the variability in PPAI. Nonetheless, the associations were consistent with our current understanding of the link between the somatotropic and reproductive axes, and do provide useful information for further studies.

Underfeeding during the final few weeks before calving appeared to create a degree of energetic stress, as indicated by elevated NEFA and BHBA. This effect was associated with a tendency for a delayed time to first ovulation. Average intakes of $4.8 \mathrm{~kg}$ of DM/d per cow equivalent to about $1 \% \mathrm{BW}$ and $51 \%$ of energy requirements (Roche et al., 2005, 2007) reduced insulin and IGF-I within several days, compared with cows on higher average DMI representing about $2.5 \% \mathrm{BW}$ and $131 \%$ of energy requirements. The elevation in GH observed just before calving among all cows was initiated earlier and was greater in magnitude in those with low feed intakes prepartum. Insulin and IGF-I enhance estrogenic function in the early postpartum dominant follicle (Spicer et al., 1993; Diskin et al., 2003). Uncoupling of the GH-IGF-I axis is a homeorhetic condition that occurs around calving in dairy cattle (Rhoads et al., 2005), and is considered to repress follicular function. Interestingly, the difference in blood concentration of IGF-I converges as the animal approaches calving, with the PreH cows declining to a greater degree than PreL cows as parturition approached. The reason for this convergence is not clear, but it may be a result of differential timing in the uncoupling of the somatotropic axis. A sustained period of negative energy balance reduced the expression of GH receptor-1A in liver tissue (Breier et al., 1988). The prepartum feed restriction may have caused the "uncoupling" of the somatotropic axis to occur earlier than would otherwise have happened; this premise is consistent with the lower IGF-I concentrations evident in the PreL treatment cows. Still, IGF-I concentration would naturally be expected to decline as parturition approached in the PreH treatment cows, causing the plasma profiles to converge in the week before calving. The evident convergence of precalving treatments in plasma NEFA and BHBA concentration in the week before calving is perplexing, because it is mainly a result of a lowering of the concentration of these metabolites in the PreL cows. It is not clear why indicators of energy balance should become more positive as calving approaches. It is interesting however, because plasma concentrations of metabolites reflecting the energy status of the cow are not greatly affected by energy consumption in the week before calving, and whatever compensatory mechanism facilitates this may be the reason for the lack of association between these metabolites and PPAI. 
The relevance of PreL on PPAI could be accounted for by the half-unit difference in BCS at calving in the current study. Previous studies show a reduction in PPAI of 3 to $4 \mathrm{~d}$ with each 0.5 -unit increase in BCS (1 to 10 scale; Grainger et al., 1982; McDougall et al., 1995a). This result reinforces the practical utility of using BCS as an indicator of long-term energetic status. The current study found a negative association between plasma albumin and PPAI at various time points through the transition period. The consistency and relevance of this association was similar to that between BCS and PPAI. Yet the mechanism by which restricted intake prepartum increased PPAI is unlikely to involve albumin specifically, because there was no dietary treatment effect on plasma albumin through the transition period. Albumin may have an important long-term regulatory influence on the reproductive axis, although the relationship between albumin and PPAI is perhaps more a consequence of altered energy balance with scavenging of circulating albumin as an amino acid source for gluconeogenesis (Bell et al., 2000).

Postpartum pasture intake did not affect PPAI, BCS, GH, IGF-I, or insulin in the current study. This pattern of response is similar to that previously reported in first-calving Holstein-Friesian heifers managed on pasture (Burke et al., 1995; Chagas et al., 2006). These studies demonstrated that the negative effect of restricted feeding prepartum in heifers is not overcome by generous pasture allowances after calving. It would appear from the present study that cows adjusted to high or low pasture intakes by producing more or less milk to best achieve a genetically determined metabolic state. Even so, metabolic state was not fully restored to that of cows on high pasture intakes as demonstrated with reduced plasma glucose and elevated NEFA and BHBA (HL treatment group only). Nevertheless, concentrations of these metabolites during the postpartum period were not associated with variance in PPAI, irrespective of treatment groups. Furthermore, the magnitude of the effect of low pasture intakes postpartum on these metabolites was insufficient to measurably affect BCS, which declined similarly whether postpartum intakes were low or high. Low postpartum intakes did reduce BW. The difference can probably be accounted for by gut content differences at the time of weighing, and potentially, reduced tissue masses at sites (e.g., muscle, internal fat, skin, udder) that would not be accounted for in BCS (Berry et al., 2007). Nevertheless, BW was less well associated with PPAI compared with BCS.

The apparent ability of these animals to easily reduce milk energy output when faced with low energy intake may be an acquired genotypic feature of cows selected for seasonal pasture-based dairy systems. Regardless, the current study shows that for a pastureonly diet, nutritional and metabolic state during the prepartum stage is the most critical period for influencing PPAI. This interpretation is consistent with the findings of others within pasture-based dairy systems (Burke et al., 1995; McDougall et al., 1995b). Chagas et al. (2006) described the prepartum nutritional effect on PPAI as one having an "endocrine memory" that recursively influences PPAI irrespective of postpartum nutrition when diet consists solely of pasture. Body condition score and GH were at least 2 variables having such carryover effects, whereas most other variables were ameliorated by postpartum nutritional conditions.

\section{CONCLUSIONS}

During the transitional period in multiparous dairy cows, restricted pasture intake prepartum reduced BCS and tended to prolong the postcalving interval to first ovulation. Postpartum intake had a substantial effect on milk production, but had no effect on PPAI. The effect of low pasture intakes prepartum was characterized with reduced IGF-I and increased GH, both of which were subsequently linked to PPAI in a treatment-independent manner. In early lactation, cows in this study adjusted milk output to match dietary intake, whereas insulin GH and IGF-I concentrations remained similar despite contrasting levels of feed intake. Still, a general conclusion is that common measures of metabolic state explained only a small amount of the variance in PPAI among the dairy cows used in this study.

Prepartum dietary energy intakes that maintain elevated insulin and IGF-I and support a desirable BCS at calving are an important consideration when pasture is the sole dietary source through the calving transition of mature dairy cows. Because much of the variance in PPAI was unaccounted for, despite considerable variation in PPAI among the cows studied, longer-term genetic selection for avoidance of cows with prolonged PPAI could be a worthwhile consideration. The results also suggest that selection against long PPAI could proceed without compromising genetic merit for milk yield, because there was no relationship among these variables.

\section{ACKNOWLEDGMENTS}

The authors are grateful for the technical support of P. W. Aspin and J. M. Lee, managerial support of A. Napper, J. Morse, P. Taylor, and all staff at Scott Farm, and the statistical support of B. Dow. 


\section{REFERENCES}

Bell, A. W., W. S. Burhans, and T. R. Overton. 2000. Protein nutrition in late pregnancy, maternal protein reserves and lactation performance in dairy cows. Proc. Nutr. Soc. 59:119-126.

Berry, D. A., K. A. Macdonald, J. W. Penno, and J. R. Roche. 2007. Association between body condition score and live weight in pasture-based Holstein-Friesian dairy cows. J. Dairy Res. 73:487-491

Breier, B. H., P. D. Gluckman, and J. J. Bass. 1988. The somatotrophic axis in young steers: Influence of nutritional status and oestradiol- $17 \beta$ on hepatic high- and low-affinity somatotrophic binding sites. J. Endocrinol. 116:169-177.

Burke, C. R., S. McDougall, and K. L. Macmillan. 1995. Effects of breed and calving liveweight on postpartum ovarian activity in pasture-fed heifers. Proc. N.Z. Soc. Anim. Prod. 55:76-78.

Butler, W. R., and R. D. Smith. 1989. Interrelationships between energy balance and postpartum reproductive function in dairy cattle. J. Dairy Sci. 72:767-783.

Chagas, L. M., F. M. Rhodes, D. Blache, P. J. S. Gore, K. A. Macdonald, and G. A. Verkerk. 2006. Precalving effects on metabolic responses and postpartum anestrus in grazing primiparous dairy cows. J. Dairy Sci. 89:1981-1989.

Darwash, A. O., G. E. Lamming, and J. A. Woolliams. 1997. The phenotypic association between the interval to post-partum ovulation and traditional measures of fertility in dairy cattle. Anim. Sci. 65:9-16.

Diskin, M. G., D. R. Mackey, J. F. Roche, and J. M. Shreenan. 2003. Effects of nutrition and metabolic status on circulating hormones and ovarian follicle development in cattle. Anim. Reprod. Sci. 78:345-370.

Formigoni, A., and E. Trevisi. 2003. Transition cow: Interaction with fertility. Vet. Res. Commun. 27:143-152.

Grainger, C., and G. D. Wilhelms. 1979. Effect of duration and pattern of underfeeding in early lactation on milk production and reproduction of dairy cows. Aust. J. Exp. Agric. Anim. Husb. 19:395-401.

Grainger, C., G. D. Wilhelms, and A. A. McGowan. 1982. Effect of body condition at calving and level of feeding in early lactation on milk production of dairy cows. Aust. J. Exp. Agric. Anim. Husb. 22:9-17.

Jolly, P. D., S. McDougall, L. A. Fitzpatrick, K. L. Macmillan, and K. W. Entwistle. 1995. Physiological effects of undernutrition on postpartum anoestrus in cows. J. Reprod. Fertil. Suppl. 49:477-492

Macmillan, K. L. 2002. Advances in bovine theriogenology in New Zealand. 1. Pregnancy, parturition and the postpartum period. N.Z. Vet. J. 50:67-73.

McDougall, S., C. R. Burke, K. L. Macmillan, and N. B. Williamson. 1995a. Patterns of follicular development during periods of anovulation in pasture-fed dairy cows after calving. Res. Vet. Sci. 58:212-216.

McDougall, S., C. R. Burke, N. B. Williamson, and K. L. Macmillan. 1995b. The effect of stocking rate and breed on the period of postpartum anoestrum in grazing dairy cattle. Proc. N.Z. Soc. Anim. Prod. 55:236-238.

McDougall, S., R. Macaulay, and C. W. R. Compton. 2007. Association between endometritis diagnosis using a novel intravaginal device and reproductive performance in dairy cattle. Anim. Reprod. Sci. 99:9-23.

McNaughton, L. R., G. A. Verkerk, T. J. Parkinson, K. A. Macdonald, and C. W. Holmes. 2003. Pospartum anoestrous intervals and reproductive performance of three genotypes of HolsteinFriesian dairy cattle managed in a seasonal pasture-based dairy system. Proc. N.Z. Soc. Anim. Prod. 63:77-81.

Opsomer, G., Y. T. Grohn, J. Hertl, M. Coryn, H. Deluyker, and A. de Kruif. 2000. Risk factors for postpartum ovarian dysfunction in high producing cows in Belgium: A field study. Theriogenology $53: 841-857$

Rhoads, R. P., M. L. Rhoads, and Y. R. Boisclair. 2005. Implications of a dysfunctional somatotropic axis during the transition period of dairy cattle. Pages 197-208 in Proc. Southwest Nutr. Conf. Univ. Arizona, Tucson.

Rhodes, F. M., S. McDougall, C. R. Burke, G. A. Verkerk, and K. L. Macmillan. 2003. Invited review: Treatment of cows with an extended postpartum anestrous interval. J. Dairy Sci. 86:1876-1894.

Robinson, J. J., C. J. Ashworth, J. A. Rooke, L. M. Mitchell, and T. G. McEvoy. 2006. Nutrition and fertility in ruminant livestock. Anim. Feed Sci. Technol. 126:259-276.

Roche, J. R. 2007. Milk production responses to pre- and postcalving dry matter intake in grazing dairy cows. Livest. Sci. 110:12-24.

Roche, J. R., P. G. Dillon, C. R. Stockdale, L. H. Baumgard, and M. J. VanBaale. 2004. Relationships among international body scoring systems. J. Dairy Sci. 87:3076-3079.

Roche, J. R., E. S. Kolver, and J. K. Kay. 2005. Influence of precalving feed allowance on peripaturient metabolic and hormonal responses and milk production in grazing dairy cows. J. Dairy Sci. 88:677-689.

Roche, J. R., K. M. Macdonald, C. R. Burke, J. M. Lee, and D. P. Berry. 2007. Associations among body condition score, body weight, and reproductive performance in seasonal-calving dairy cattle. J. Dairy Sci. 90:376-391.

Sauer, M. J., J. A. Foulkes, A. Worsfold, and B. A. Morris. 1986. Use of progesterone 11-glucuronide-alkaline phosphatase conjugate in a sensitive microtitre-plate enzyme immunoassay of progesterone in milk and its application to pregnancy testing in dairy cattle. J. Reprod. Fertil. 76:375-391.

Spicer, L. J., E. Alpizar, and S. E. Echternkamp. 1993. Effects of insulin, insulin-like growth factor I, and gonadotropins on bovine granulosa cell proliferation, progesterone production, estradiol production, and (or) insulin-like growth factor I production in vitro. J. Anim. Sci. 71:1232-1241.

Verbyla, A. P., B. R. Cullis, M. G. Kenward, and S. J. Welham. 1999. The analysis of designed experiments and longitudinal data by using smoothing splines (with discussion). Appl. Stat. 48:269311.

Westwood, C. T., I. J. Lean, and J. K. Garvin. 2002. Factors influencing fertility of Holstein dairy cows: A multivariate description. J. Dairy Sci. 85:3225-3237. 